\title{
Malic enzyme is present in mouse islets and modulates insulin secretion
}

\author{
J. Xu • J. Han • Y. S. Long • J. Lock • G. C. Weir • \\ P. N. Epstein • Y. Q. Liu
}

Received: 17 July 2008 / Accepted: 18 August 2008 / Published online: 19 September 2008

(C) Springer-Verlag 2008

\begin{abstract}
Aims/hypothesis The pyruvate-malate shuttle is a metabolic cycle in pancreatic beta cells and is important for beta cell function. Cytosolic malic enzyme (ME) carries out an essential step in the shuttle by converting malate to pyruvate and generating NADPH. In rat islets the pyruvate-malate shuttle may regulate insulin secretion and it has been shown to play a critical role in adaptation to obesity and insulin resistance. However, ME has not been demonstrated in mouse islets and three reports indicate that mouse islets contain no $\mathrm{ME}$ activity. If mouse islets lack ME, rat and mouse islets must regulate insulin secretion by different mechanisms.

Methods We measured ME activity by a fluorometric enzymatic assay and Me mRNA by real-time PCR. ME activity was also measured in streptozotocin-treated mouse
\end{abstract}

J. Xu and J. Han contributed equally to this study.

Electronic supplementary material The online version of this article (doi:10.1007/s00125-008-1155-0) contains supplementary material, which is available to authorised users.

J. Xu · J. Han · Y. S. Long • P. N. Epstein · Y. Q. Liu ( $\bowtie)$

Kosair Children's Hospital Research Institute,

Department of Pediatrics,

University of Louisville School of Medicine,

Louisville, KY, USA

e-mail: yliu@chnola-research.org

J. Han · Y. Q. Liu

The Research Institute for Children, Children's Hospital,

200 Henry Clay Avenue,

New Orleans, LA 70118, USA

J. Lock $\cdot$ G. C. Weir

Joslin Diabetes Center, One Joslin Place,

Harvard Medical School,

Boston, MA, USA islets. FACS-purified beta cells were obtained from MIPGFP mouse islets, agouti-L obese mouse islets and mouse beta cell line MIN-6. Insulin secretion and NADPH/ $\mathrm{NADP}^{+}$ratios were measured in $\mathrm{Me}$ siRNA-treated beta cells.

Results ME activity and Me mRNA were present in C57BL/6 mouse islets. ME activity was reduced in streptozotocintreated mouse islets. ME activity was also measurable in FACS-purified mouse beta cells. In addition, ME activity was significantly increased in obese agouti-L mouse islets and the mouse MIN-6 cell line. Me siRNA inhibited ME activity and reduced glucose-stimulated insulin secretion and also inhibited NADPH products.

Conclusions/interpretation Mouse islets contain ME, which plays a significant role in regulating insulin secretion.

Keywords Insulin secretion - Islet of Langerhans .

Malic enzyme $\cdot$ MIN-6 cells $\cdot$ Pyruvate-malate shuttle

$\begin{array}{ll}\text { Abbreviations } \\ \text { AyL } & \text { agouti-L obese mouse } \\ C_{\mathrm{t}} & \text { cycle threshold } \\ \text { DTT } & \text { dithiothreitol } \\ \text { GFP } & \text { green fluorescent protein } \\ \text { GSIS } & \text { glucose-stimulated insulin secretion } \\ \text { ME } & \text { cytosolic malic enzyme } \\ \text { SiRNA } & \text { small interfering RNA } \\ \text { STZ } & \text { streptozotocin }\end{array}$

\section{Introduction}

Cytosolic malic enzyme (ME or ME1, EC 1.1.1.40) is a key component in the pyruvate-malate shuttle $[1,2]$, which is a 
major source of cytoplasmic NADPH. In this shuttle, pyruvate is converted to oxaloacetate by pyruvate carboxylase within the mitochondria. Malate dehydrogenase converts the oxaloacetate to malate, which is released into the cytosol and converted back to pyruvate by ME. The conversion of malate to pyruvate by ME produces one molecule of NADPH. In pancreatic beta cells the pyruvate-malate shuttle produces significantly more NADPH than the pentose phosphate shuttle [1]. NADPH-producing enzymes are essential to all living organisms because they play a key role in biosynthetic processes and in regulating cellular redox status [3]. Specifically, NADPH is pivotal in lipid and fatty acid synthesis [4, 5], cellular replication and the inhibition of apoptosis [6-8]. In addition, oxaloacetate, an intermediate in the pyruvate-malate shuttle, can be converted to aspartate, a precursor in protein synthesis [9]. In the pancreatic beta cell, an additional important role of NADPH may be regulation of glucose-stimulated insulin secretion (GSIS) [1, 10, 11]. Therefore, in the beta cell the pyruvate-malate shuttle plays a role in metabolism, insulin secretion and cell proliferation. This has been demonstrated in rat islets [1, 12-17].

$\mathrm{ME}$ is also part of an active pyruvate-citrate shuttle, and this cycle may also regulate GSIS [18, 19]. In this cycle, pyruvate enters the Krebs cycle via pyruvate carboxylase and then oxaloacetate [20]. The latter is converted to citrate, which accumulates within the mitochondria. Mitochondrial citrate is then exported into the cytoplasm by the tricarboxylate carrier in exchange for malate. In the cytosol, ATP-citrate lyase cleaves citrate into acetyl-CoA and oxaloacetate. The latter is converted to malate by malate dehydrogenase. Malate is then converted back into pyruvate by ME, and produces NADPH.

Previous studies [21, 22] reported that mouse islets, unlike rat islets, do not possess ME activity. This observation was supported by another report that showed ME activity in mouse islets was below the level of detection [23]. This would be critical because it would imply that mouse and rat beta cells use different mechanisms to regulate insulin secretion. Because we have been studying pyruvate carboxylase and the pyruvate-malate shuttle in mouse beta cells for some time, it was of interest to re-evaluate whether ME is present in mouse islets. Thus, in this study, we measured ME activity and Me mRNA in C57BL/6 mouse islets. We also measured ME activity in islets with or without in vitro streptozotocin (STZ) treatment, in islets of obese agouti-L mice (AyL, C57BL/6 background) and in purified beta cells from C57BL/6 mouse islets. All of these results indicate that ME is present in mouse beta cells, albeit at lower levels than in rat islets. Second, using small interfering RNA (siRNA) to inhibit ME activity, we showed that ME modulates NADPH production and GSIS in dispersed beta cells from C57BL/6 mouse islets and in the mouse beta cell line MIN-6.

\section{Methods}

Animals The principles of animal laboratory care under the guidelines of the National Institutes of Health, USA, the University of Louisville and The Research Institute in New Orleans Children's Hospital's Animal Care Committee were strictly followed. Male C57BL/6 mice, AyL mice (all from Jackson Laboratory, Bar Harbor, ME, USA) and SpragueDawley (SD) rats (Taconic, Germantown, NY, USA) from 9 to 15 weeks of age were used for this research. The animals received normal chow and were housed in the Animal Care Facility at the University of Louisville and The Research Institute in New Orleans Children's Hospital and maintained at $25^{\circ} \mathrm{C}$ with a $12 \mathrm{~h}$ light-dark cycle. MIP-GFP C57BL/6 mice, carrying a transgene for green fluorescent protein (GFP) regulated by the mouse insulin promoter, were provided by M. Hara [24] (University of Chicago) and were housed in the Joslin Diabetes Center.

Islet isolation and separation of islets into single cells Islets were isolated from rats and mice by an adaptation of the method of Gotoh et al. [25]: infiltration of pancreas ducts with collagenase, followed by Histopaque (Sigma, St Louis, MO, USA) gradient separation and hand selection. For separation of islets into single cells, mouse islets were digested with $0.25 \%$ trypsin for $5 \mathrm{~min}$; incompletely digested islets were separated into single cells by passing them through a $200 \mu \mathrm{l}$ pipette tip. Islet cells were cultured at $37^{\circ} \mathrm{C}$ in humidified air and 5\% $\mathrm{CO}_{2}$ in RPMI 1640 medium containing $5.5 \mathrm{mmol} / \mathrm{l}$ glucose, $10 \%$ newborn calf serum, $2 \mathrm{mmol} / \mathrm{l}$ glutamine, $100 \mathrm{U} / \mathrm{ml}$ penicillin and $0.1 \mathrm{mg} / \mathrm{ml}$ streptomycin (all from Gibco, Grand Island, NY, USA).

In vitro STZ treatment $\mathrm{STZ}$ was prepared $1 \mathrm{~min}$ before use by dissolving in $0.1 \mathrm{~mol} / 1$ sodium citrate $(\mathrm{pH} 4.5)$ at $4^{\circ} \mathrm{C}$ at a concentration of $200 \mathrm{mmol} / \mathrm{l}$. Ten microlitres of this solution was added to the islets to obtain $1 \mathrm{mmol} / \mathrm{l} \mathrm{STZ}$. Islets were then incubated overnight $(18 \mathrm{~h})$.

Islet DNA, protein and insulin content assay, and insulin protein determination Islet DNA content was measured by the method of Labarca and Paigen [26] and protein content was determined using a commercial kit (Bio-Rad, Hercules, CA, USA) with BSA as standard. Insulin protein content in STZ-treated islets was determined by western blotting using insulin antibody.

MIN-6 cell culture The mouse insulinoma cell line MIN-6 was provided by S. Ozcan (University of Kentucky) at passage 24-30. The cells were cultured as described previously [27] in DMEM containing $4.5 \mathrm{~g} / 1$ glucose, $70 \mu \mathrm{mol} / 1 \quad \beta$-mercaptoethanol, $1 \%$ penicillin/streptomycin and $15 \% \mathrm{FCS}$ at $37^{\circ} \mathrm{C}$ in a humidified atmosphere with $5 \%$ 
$\mathrm{CO}_{2}$. The cells were subcultured by digestion with $0.25 \%$ trypsin at $37^{\circ} \mathrm{C}$ for $5 \mathrm{~min}$, followed by centrifugation. The medium was changed every 3 days.

Insulin secretion and insulin assay Insulin secretion was measured by a previously described method [14]. Insulin secreted into KRB buffer was measured using an ELISA insulin assay kit (Linco Research, St Charles, MO, USA).

Purification of mouse beta cells producing green fluorescent protein Mouse islet isolation from 6- to 8-week-old MIP-GFP transgenic mice and beta cell purification were performed at the Joslin Diabetes Center. Islets were isolated using a modification of the method of Gotoh et al. [25]. The hand-picked islets were dispersed to single cells as previously described [28]. In brief, the islets were washed with PBS and suspended in a solution of trypsin (Sigma) and DNase 1 (Roche, Indianapolis, IN, USA) then incubated for $15 \mathrm{~min}$ at $37^{\circ} \mathrm{C}$. The islets were gently vortexed at $5 \mathrm{~min}$ intervals, washed at the end of the digestion and then filtered through a $40 \mu \mathrm{m}$ filter for sorting. Single cells were sorted for production of GFP on a Mo-Flo (Dako Cytomation, Carpinteria, CA, USA) FACS sorter. The green insulinproducing cells were collected and washed with PBS then lysed in $30 \mu \mathrm{l}$ homogenisation buffer (see ME activity assay) by sonication (Sonic Dismembrator; Fisher Scientific, Pittsburgh, PA, USA) and frozen. The frozen extracts were shipped overnight to our laboratory in Louisville for the enzyme activity assay. Intact islets were homogenised, frozen and shipped similarly to the purified beta cells, for measurement of ME activity.

ME activity assay Islets, beta cells or liver tissues were washed three times with PBS then homogenised in buffer containing $10 \mathrm{mmol} / 1 \mathrm{HEPES}, \mathrm{pH}$ 7.4, $250 \mathrm{mmol} / 1$ sucrose, $2.5 \mathrm{mmol} / \mathrm{l}$ EDTA, $2 \mathrm{mmol} / \mathrm{l}$ cysteine and $0.02 \%$ BSA (wt/vol). To compare the effects of different homogenisation buffers on ME activity, rat or mouse islets were also homogenised in a buffer containing $220 \mathrm{mmol} / 1$ mannitol, $70 \mathrm{mmol} / 1$ sucrose, $5 \mathrm{mmol} / \mathrm{l}$ potassium HEPES buffer, $\mathrm{pH} 7.5$, and $1 \mathrm{mmol} / \mathrm{l}$ dithiothreitol (DTT) as previously described [21]. The homogenate was centrifuged at $10,000 \mathrm{~g}$ for $15 \mathrm{~min}$ and the supernatant fraction was collected for ME activity and protein assays. All buffers were kept cold on ice prior to enzyme assay. Cell extract (20-40 $\mu \mathrm{g}$ protein) or NADPH standard (1-100 nmol) were added to $1 \mathrm{ml}$ of reaction buffer $(50 \mathrm{mmol} / 1 \mathrm{Tris}-\mathrm{HCl}$, $\mathrm{pH} 7.8,4 \mathrm{mmol} / 1 \mathrm{MgCl}_{2}, 0.1 \mathrm{mmol} / 1 \mathrm{NADP}^{+}$and $1 \mathrm{mmol} / 1$ malate). The change in fluorescence from 1 to $10 \mathrm{~min}$ was measured at room temperature with excitation at $340 \mathrm{~nm}$ and emission at $420 \mathrm{~nm}$ using a Hitachi F-2500 Fluorescence Spectrophotometer (Pleasanton, CA, USA). Actual sample values were obtained by subtracting blank values (without cell extracts) from sample values (with cell extracts). $\mathrm{ME}$ activities in C57BL/6 mouse liver and SD rat islet extracts were measured as a positive control; partial extracts were heated at $100^{\circ} \mathrm{C}$ for $10 \mathrm{~min}$ as a negative control.

Total RNA extraction from liver tissues and cultured islets, quantitative PCR and real-time PCR A small piece of tissue (about $10-30 \mathrm{mg}$ ) was cut from the right leaf of the liver and sliced. The sliced liver tissues were put into a $1.5 \mathrm{ml}$ RNasefree pellet pestle/homogenising tube (Kontes Glass, Vineland, NJ, USA), and $600 \mu$ RLT lysis buffer was added. The liver tissues were homogenised by thorough grinding and centrifuged at $15,000 \mathrm{~g}$ for $3 \mathrm{~min}$. Islets were washed with PBS (free of $\mathrm{Mg}^{2+}$ and $\mathrm{Ca}^{2+}$ ), digested with $0.25 \%$ trypsin (Invitrogen, Calsbad, CA, USA) for 5-15 min, then ice cold RPMI 1640 (containing 10\% newborn calf serum) was added to stop the digestion. The cells and liver tissues were transferred to a $10 \mathrm{ml}$ sterile RNase-free tube and were washed and centrifuged three times at $300 \mathrm{~g}$ at $4^{\circ} \mathrm{C}$ for $4 \mathrm{~min}$. Total cellular RNA was isolated from islets and liver tissues using an RNeasy Mini kit (Qiagen, Valencia, CA, USA) according to protocol and the RNA concentration was determined using a RiboGreen RNA Quantisation kit (Molecular Probes, Eugene, OR, USA). cDNA synthesis was carried out using Brilliant quantitative (q) PCR kit (Stratagene, La Jolla, CA, USA) according to the manufacturer's protocol. Universal PCR Master Mix (Applied Biosystems) was diluted according to the manufacturer's procedure for qPCR [29]. The final concentration of primer was $0.9 \mu \mathrm{mol} / \mathrm{l}$ and that of the probe was $0.25 \mu \mathrm{mol} / \mathrm{l}$. Relative copy numbers were calculated using the method of Pfaffl [30]. The sequences designed for detecting $M e$ gene expression by real-time-PCR in mouse beta cells are shown in the Electronic supplementary material (ESM; ESM Table 1).

Me siRNA transfection Me siRNA transfection was carried out according to the Stealth RNA transfection protocol (Invitrogen) and the cells were cultured for $48 \mathrm{~h}$. The sequences designed for inhibiting $\mathrm{Me}$ gene expression in mouse beta cells are shown in ESM Table 1.

$\mathrm{NADPH}$ and $\mathrm{NADP}^{+}$measurement $\mathrm{NADPH}$ or $\mathrm{NADP}^{+}$ content in the extract was measured by a modified method [31] based on a cycling method described by Lowry and Passonneau [32].

Data presentation and statistical methods All data are expressed as mean $\pm \mathrm{SEM}$. The listed $n$ values represent the number of a single experiment performed (each experiment was duplicated). Comparisons between two groups were performed by Student's $t$ test. Comparisons between multiple groups were performed by one- or two-way ANOVA (Tukey post hoc test). A value of $p<0.05$ was considered significant. 


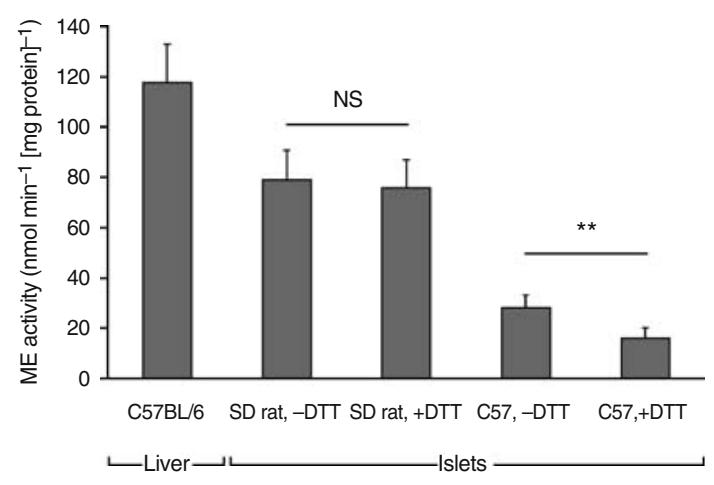

Fig. $1 \mathrm{ME}$ activity was measurable in $\mathrm{C} 57 \mathrm{BL} / 6$ mouse islets. ME activity levels in C57BL/6 mouse liver and rat islets were used as positive controls. Data are mean \pm SEM, $n=4$. - DTT, standard homogenisation buffer without DTT; +DTT homogenisation buffer containing $1 \mathrm{mmol} / 1 \mathrm{DTT}$; NS, not significant. ${ }^{* *} p<0.01$

\section{Results}

$M E$ activity and $\mathrm{Me} m R N A$ in mouse islets Initially, ME activity was measured in $\mathrm{C} 57 \mathrm{BL} / 6$ mouse liver and SD rat islets to serve as positive controls (Fig. 1). ME activity in C57BL/6 mouse liver was about $120 \mathrm{nmol} \mathrm{m^{-1 }}$ (mg protein) ${ }^{-1}$ and activity in SD rat islets was just under $80 \mathrm{nmol} \mathrm{min}^{-1}$ (mg protein $)^{-1}$. In C57BL/6 mouse islets, ME activity was about

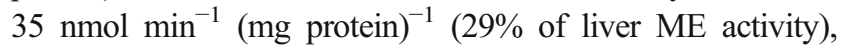
demonstrating that ME activity was detectable in mouse islets. Mouse islet ME activity was significantly reduced by DTT, but rat islet $\mathrm{ME}$ was not. The previous report [21] that $\mathrm{ME}$ was not detectable in mouse islets may have been in part due to the inclusion of DTT in the homogenisation buffer used in that study.

To make sure measured ME activity was real enzyme activity, we performed several blank and negative control measurements. As shown in Table 1, we could not measure $\mathrm{ME}$ activity if islet extract, $\mathrm{NADP}^{+}$or malate was not added to the reaction buffer. Rat islet and mouse liver extracts were used as positive controls. As a negative control, we denatured islet or liver extract by heating it at $100^{\circ} \mathrm{C}$ for $10 \mathrm{~min}$. No enzyme activity could be measured in these denatured extracts. These control assays indicates that ME activity can be measured in our assay system.

To further support our findings of ME activity in mouse islets, we measured $M e$ mRNA in mouse islets by Taqman real-time PCR. As shown in Table 2, Me mRNA was expressed in C57BL/6 mouse islets, with a cycle threshold $\left(C_{\mathrm{t}}\right)$ about five cycles greater than the $C_{\mathrm{t}}$ for actin mRNA. As a positive control, $\mathrm{C} 57 \mathrm{BL} / 6$ mouse liver was found to contain higher levels of $M e$ mRNA, with a $C_{\mathrm{t}}$ three cycles after actin. Based on the calculation, $M e$ mRNA expression level in the islets was $22 \%$ of liver $M e$ mRNA. This
Table 1 Assay conditions used for measuring ME activity

\begin{tabular}{|c|c|c|c|c|}
\hline \multirow{2}{*}{$\begin{array}{l}\text { Tissue } \\
\text { extract }^{\text {a }}\end{array}$} & \multicolumn{3}{|c|}{ Assay conditions } & \multirow{2}{*}{$\begin{array}{l}\text { ME activity } \\
\left(\text { nmol } \min ^{-1}\right. \\
{[\text { mg protein }}\end{array}$} \\
\hline & $\mathrm{NADP}^{+\mathrm{b}}$ & Malate $^{\mathrm{b}}$ & Heating $^{\mathrm{c}}$ & \\
\hline No extract & + & + & - & 0 \\
\hline Mouse islet & - & - & - & 0 \\
\hline Mouse islet & + & - & - & 0 \\
\hline Mouse islet & - & + & - & 0 \\
\hline Mouse islet & + & + & - & $28.2 \pm 6.4$ \\
\hline Mouse islet & + & + & + & 0 \\
\hline Rat islet & + & - & - & 0 \\
\hline Rat islet & - & + & - & 0 \\
\hline Rat islet & + & + & - & $82.4 \pm 21.6$ \\
\hline Rat islet & + & + & + & 0 \\
\hline Mouse liver & + & + & - & $115.6 \pm 32.8$ \\
\hline Mouse liver & + & + & + & 0 \\
\hline
\end{tabular}

Data are mean \pm SEM; $n=5$

${ }^{\mathrm{a}}$ Forty micrograms of mouse islet protein and $20 \mu \mathrm{g}$ of rat islet and mouse liver protein were used for each individual enzyme activity assay

${ }^{\mathrm{b}}$ Components and concentrations of $\mathrm{NADP}^{+}$and malate in the reaction solution are described in Materials and methods

${ }^{\mathrm{c}}$ Tissue extracts were heated to $100^{\circ} \mathrm{C}$ for $10 \mathrm{~min}$ before the enzyme activity assay

percentage of Me mRNA level in the islets compared with liver was similar to the percentage difference in enzyme activity (29\%; Fig. 1).

ME activity in STZ-treated C57BL/6 mouse islets Since STZ specifically destroys beta cells [33], it was used in the following experiment. Isolated C57BL/6 mouse islets were treated with $1 \mathrm{mmol} / 1 \mathrm{STZ}$ for $18 \mathrm{~h}$ (Fig. 2), followed by measurement of islet protein, DNA and ME activity. Protein and DNA contents were reduced to about 22 and $39 \%$ of controls, respectively, in STZ-treated islets, suggesting that most beta cells were destroyed. As shown in Fig. 2c, the ME activity in STZ-treated islets was reduced to $24 \%$ of control; probably as a result of the destruction of many beta cells in the islets. The loss of beta cells is demonstrated in Fig. 2d, which shows that the insulin content detected by western blotting in STZ-treated islets was significantly reduced ( $20 \%$ of control).

ME activity in purified mouse islet beta cells In order to exclude all non-beta cells from the ME assays, we purified primary beta cells from the islets of MIP-GFP transgenic mice, which produce GFP only in beta cells, by FACS sorting. As shown in Fig. 3, ME activity was measurable (about 9 nmol $\min ^{-1}[\mathrm{mg} \text { protein }]^{-1}$ ) in pure C57BL/6 mouse beta cells, thus demonstrating that mouse beta cells possess ME activity. ME activity in pure beta cells was about $30 \%$ of whole islet ME activity (about $28 \mathrm{nmol} \mathrm{min} \mathrm{m}^{-1}$ 
Table 2 Relative quantitation of Me mRNA expression in mouse liver and islets using a comparative $C_{\mathrm{t}}$ method [50]

\begin{tabular}{lccllr}
\hline Tissue & Me average $C_{\mathrm{t}}$ & Actin average $C_{\mathrm{t}}$ & $\begin{array}{l}\Delta C_{\mathrm{t}} \\
M e-\operatorname{actin}^{\mathrm{a}}\end{array}$ & $\begin{array}{l}\Delta \Delta C_{\mathrm{t}} \\
\Delta C_{\mathrm{t}}-\Delta C_{\mathrm{t}}, \text { liver }^{\mathrm{b}}\end{array}$ & \multicolumn{1}{c}{$M e$ relative to liver } \\
\hline Liver & $17.41 \pm 0.39$ & $14.32 \pm 0.23$ & $3.09 \pm 0.45$ & $0.00 \pm 0.45$ & $1.01(0.73-1.37)$ \\
Islet & $20.75 \pm 0.28$ & $15.50 \pm 0.04$ & $5.25 \pm 0.28$ & $2.16 \pm 0.28$ & $0.22(0.18-0.27)$ \\
\hline
\end{tabular}

Me mRNA expression levels in C56BL/6 mouse islet and liver were determined by real-time PCR

Me mRNA expression levels in liver were used as a positive control

Me mRNA expression levels in mouse islets were compared with those in liver and presented as a relative value $(n=4)$

${ }^{\text {a }}$ The $\Delta C_{\mathrm{t}}$ value was determined by subtracting the average actin $C_{\mathrm{t}}$ value from the average $M e C_{\mathrm{t}}$ value. The standard deviation of the difference was calculated from the standard deviations of the $M e$ and actin values

${ }^{\mathrm{b}}$ The calculation of $\Delta \Delta C_{\mathrm{t}}$ involved subtraction by the $\Delta C_{\mathrm{t}}$ calibrator value. This was subtraction of an arbitrary constant, so the standard deviation of $\Delta \Delta C_{\mathrm{t}}$ was the same as the standard deviation of the $\Delta C_{\mathrm{t}}$ value

${ }^{\mathrm{c}}$ The range given for $M e$ relative to brain was determined by evaluating the expression $2-\Delta \Delta C_{\mathrm{t}}$ with $\Delta \Delta C_{\mathrm{t}}+s$ and $\Delta \Delta C_{\mathrm{t}}-s$, where s is the standard deviation of the $\Delta \Delta C_{\mathrm{t}}$ value

[mg protein $]^{-1}$ ), suggesting that ME activity is lost during the purification process.

ME activity in obese mouse islets and MIN-6 cells We measured islet ME activity in 15-week-old obese AyL mice. These mice have an enlarged beta cell mass in response to the insulin resistance of obesity but are not diabetic [34]. As shown in Fig. 4a, islet ME activity in AyL was increased more than twofold. ME is known to be produced in mouse MIN-6 cells [21]. To find out whether ME activity is increased in MIN-6 cells compared with primary mouse
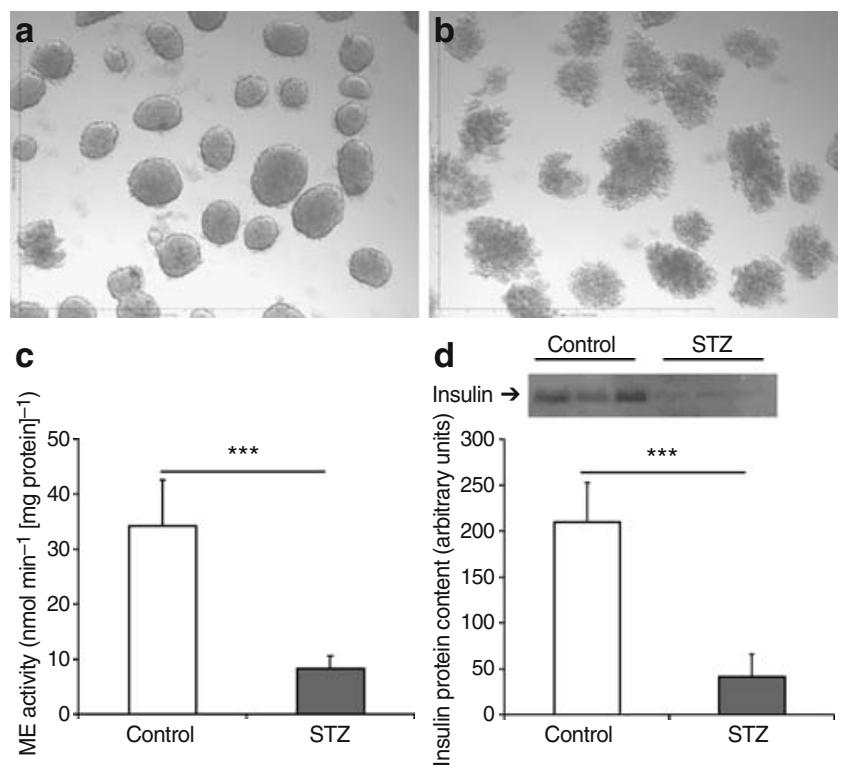

Fig. $2 \mathrm{STZ}$ treatment $(1 \mathrm{mmol} / \mathrm{l}$ for $18 \mathrm{~h})$ destroyed most beta cells and significantly reduced ME activity. a Representative micrograph of control islets. b Representative micrograph of STZ-treated islets. c Islet ME activity $(n=4)$. d Insulin protein levels in the islets detected by western blotting. The panel above the graph shows the western blot (each lane in the control and STZ-treated groups was loaded with islet protein extract [30 islets per lane] obtained from one mouse); the graph shows the protein band quantification $(n=3)$. Data are mean \pm SEM. ${ }^{* * *} p<0.001$ islets, we measured ME activity in MIN-6 cells and C57BL/6 mouse islets. As shown in Fig. 4b, ME activity was increased 2.5-fold in MIN-6 cells compared with C57BL/6 mouse islets, indicating that $\mathrm{ME}$ was upregulated by transformation.

Me siRNA treatment reduced ME activity and GSIS- but not KCl-stimulated insulin secretion in beta cells $\mathrm{ME}$ is a key component of the pyruvate-malate shuttle and its product, $\mathrm{NADPH}$, may be involved in the regulation of insulin secretion. To determine whether ME activity is involved in the regulation of GSIS, we treated dispersed single cells obtained from C57BL/6 mouse islets and the mouse beta cell line MIN-6 with Me siRNA to reduce ME activity. Two days after siRNA treatment, ME activity was reduced by about $50 \%$ in both cell types (Fig. $5 \mathrm{a}, \mathrm{c}$ ). Since there is no commercially available antibody for ME, we did not determine ME protein levels in the siRNA-treated cells. As shown in Fig. 5b and d, GSIS was significantly reduced in both cell types, supporting a role for ME in determining the rate of insulin secretion. However, Me siRNA did not block KCl-stimulated insulin secretion in the beta cells (Fig. 5b,d), suggesting that $\mathrm{KCl}$ and $\mathrm{ME}$ regulated insulin secretion by different mechanisms.

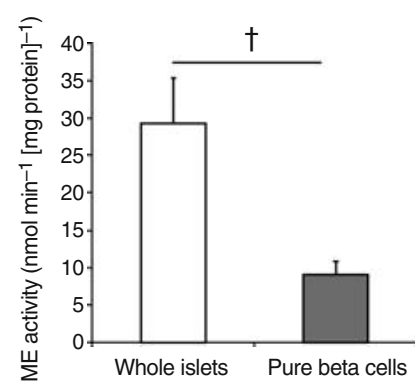

Fig. 3 ME activity was detectable in primary beta cells purified by FACS sorting from C57BL/6 beta cell GFP transgenic islets. A portion of the whole islets was saved before beta cell purification for use as positive control. Data are mean $\pm \operatorname{SEM}(n=3) .{ }^{\dagger} p=0.022$ 

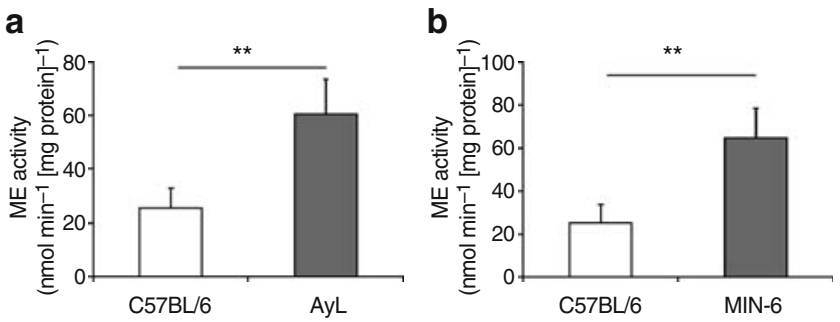

Fig. 4 ME activity was increased in islets isolated from 15-week-old obese agouti-L mice (a) and in MIN-6 cells (b). Data are mean \pm SEM $(n=6) .{ }^{*} * p<0.01$

NADPH/NADP $P^{+}$ratios in beta cells were elevated in response to high glucose and this elevation was suppressed by Me siRNA In beta cells, the pyruvate-malate shuttle plays a predominant role in producing NADPH, which may regulate insulin secretion [1]; therefore, we measured NADPH/ $\mathrm{NADP}^{+}$ratios in dispersed C57BL/6 mouse islet single cells and MIN-6 cells treated or not treated with $M e$ siRNA. As shown in Fig. 6, a high glucose concentration elevated the $\mathrm{NADPH} / \mathrm{NADP}^{+}$ratio in the cells not treated with siRNA, and $M e$ siRNA partially but significantly reduced this elevation, supporting the idea that ME produces NADPH and contributes to the regulation of GSIS.
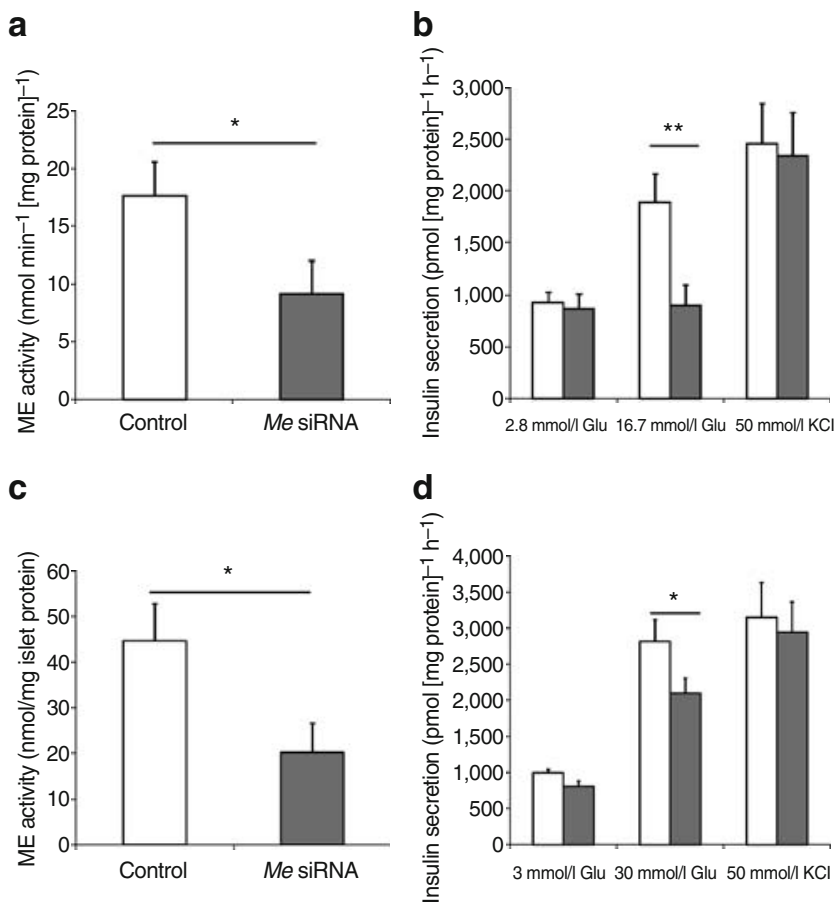

Fig. $5 \mathrm{Me}$ siRNA treatment (grey columns) significantly reduced ME activity (a and $\mathbf{c}$ ) and GSIS (b and $\mathbf{d}$ ) in both dispersed single cells of C57BL/6 mouse islets (a and b) and MIN-6 cells (c and d), but could not reduce $\mathrm{KCl}$-stimulated insulin secretion (b and $\mathbf{d})$ in these cells. Control cells (white columns) were treated with scrambled RNA sequences (see ESM Table 1). Glu, glucose. Data are mean \pm SEM $(n=4) .{ }^{*} p<0.05$, $*^{*} p<0.01$

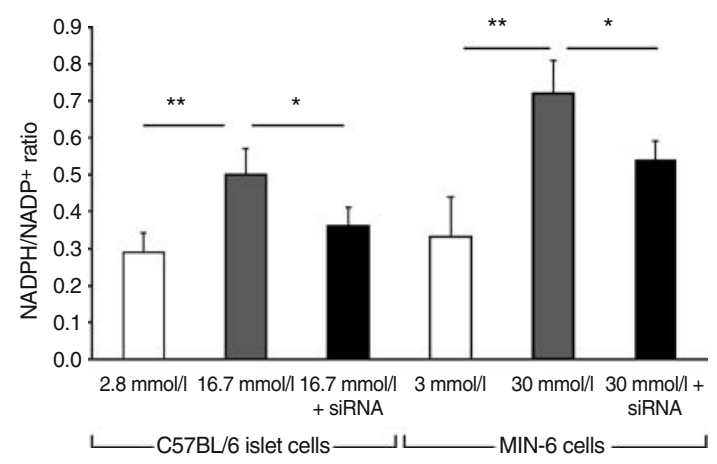

Fig. $6 \mathrm{NADPH} / \mathrm{NADP}^{+}$ratios were elevated in response to high glucose in both dispersed single cells of C57BL/6 mouse islets and MIN-6 cells; this elevation was significantly suppressed by Me siRNA treatment. After 2 days of siRNA treatment, the cells were incubated for $1 \mathrm{~h}$ in culture medium with the concentrations of glucose shown in the figure, and the cells were then used for NADPH and NADP assays. White and grey columns indicate treatment of cells with scrambled siRNA. Data are mean $\pm \operatorname{SEM}(n=5) .{ }^{*} p<0.05,{ }^{*} p<0.01$

\section{Discussion}

We obtained the following lines of evidence to support the presence and functional importance of ME in mouse islets: (1) measurable ME activity and Me mRNA were detected in C57BL/6 mouse islets; (2) ME activity was reduced in STZ-treated C57BL/6 mouse islets; (3) ME activity could be measured in FACS-purified C57BL/6 mouse beta cells; (4) elevated ME activity was observed in islets isolated from obese AyL mice and in MIN-6 cells; and (5) Me siRNA significantly reduced ME activity, NADPH products and GSIS in dispersed single cells of C57BL/6 mouse islets and MIN-6 cells. In addition, our results are supported by a recent report from Matschinsky's laboratory [35], which showed that mouse islets express $M e$ mRNA, and that cytosolic ME is involved in pyruvate-malate shuttle activity.

MacDonald [21] reported that ME is not present in mouse islets. In our assay we used a more sensitive fluorometric assay of ME and a homogenisation buffer different from that used by MacDonald; his buffer included $1 \mathrm{mmol} / \mathrm{l}$ DTT and ours did not. Perhaps our homogenisation buffer helps preserve ME activity in mouse islets. We found that $1 \mathrm{mmol} / \mathrm{l}$ DTT reduced ME activity in mouse islets by about twofold, but this level of DTT did not affect activity in rat islets (Fig. 1), suggesting that mouse islet ME might be particularly sensitive to DTT. Even in the absence of DTT, mouse islet ME activity was $60 \%$ lower than rat islet ME activity. It is possible that the previous study [21] did not demonstrate mouse islet ME activity because it is very low and is inhibited by DTT. We tested MacDonald's assay condition and found that many more mouse islets were needed for a single assay to measure ME activity using a spectrometer (data not shown). In another report 
[23], the authors used a sensitive fluorimeter and showed that ME activity in mouse islets was below the level of detection. We also tested their assay conditions [23]; our result showed that $20 \mu \mathrm{g}$ of islet protein was not enough for a single assay to measure ME activity (data not shown).

In detecting ME activity in mouse islets, a concern is contamination from exocrine cells that contain almost tenfold higher ME activity than mouse islets (data not shown). Thus, it would require $10 \%$ contamination with acinar cells to obtain the level of ME activity we found in mouse islets. As described in the Materials and methods section, islets went through four washes, including one handpicked wash. This produces over a billionfold dilution of any extracellular enzyme. We also carefully counted cell contamination under the microscope in our final preparation and this was fewer than 50 contaminating cells (not stained for amylase) in each batch of 40 islets. This would produce at most a level of contamination of $0.125 \%$, which is far too low to account for the ME activity we found in mouse islets.

Detection of $M e$ mRNA in islets provided further evidence consistent with the presence of ME enzyme in islets. In addition, ME activity was significantly reduced fivefold in STZ-treated mouse islets (Fig. 2c); this was consistent with the remaining beta cells in STZ-treated mouse islets (Fig. 2d). Since STZ primarily damages beta cells, this suggests that islet ME activity declined after STZ treatment because it was present in beta cells. Further evidence was obtained by the detection of ME activity in FACS-purified MIP-GFP mouse beta cells (Fig. 3), from which all non-beta cells were excluded. However, the activity in the purified beta cells was significantly lower than that in whole islets. Two possible explanations for this result are: (1) most islet ME activity is present in non-beta cells; and (2) ME may be sensitive to the purification procedures, and this could reduce ME activity.

To test whether ME has a role in GSIS, we used siRNA to inhibit ME activity in two beta cell types, dispersed single cells of C57BL/6 mouse islets and cells of the mouse beta cell line MIN-6. We then measured GSIS in the presence of low and high glucose. Measurable ME activity in MIN-6 cells has been reported previously $[21,36]$. We found that, in MIN-6 cells and dispersed C57BL/6 beta cells, Me siRNA significantly reduced both ME activity and GSIS (Fig. 5). However, Me siRNA did not reduce $\mathrm{KCl}$-induced insulin secretion because $\mathrm{KCl}$ stimulates insulin secretion by regulating $\mathrm{Ca}^{2+}$ flux $[37,38]$. The mechanism of reduced GSIS in these cells following siRNA inhibition of ME is uncertain but could be a decrease in flux through the pyruvate-malate shuttle with a resulting decline in NADPH production [2, 39]. Our data shown in Fig. 6 support this hypothesis; Me siRNA significantly reduced the NADPH/ $\mathrm{NADP}^{+}$ratio in beta cells. Recently, Pongratz et al. [40] showed that $\mathrm{ME}$ is important for insulin secretion in rat INS-1 cells. However, this finding would be less important if
ME were neither present nor important for insulin secretion in mouse beta cells. Our results not only show that ME is present in mouse islets but also demonstrate that ME participates in the regulation of GSIS.

The pyruvate-malate and pyruvate-citrate shuttles are part of anaplerosis and cataplerosis [41, 42]. Anaplerosis is initiated by pyruvate carboxylase, which produces oxaloacetate. In the pyruvate-citrate shuttle citrate is converted to oxaloacetate and accumulates within the mitochondria [43], or it can be exported into the cytoplasm. In the cytosol, citrate is converted to acetyl-CoA and oxaloacetate. The latter is converted to malate by malate dehydrogenase. Malate is then converted back to pyruvate by ME, and NADPH is produced in this reaction. Cytosolic citrate may be an essential component of a pyruvate-citrate shuttle, generating cytosolic acetyl-CoA, $\mathrm{NAD}^{+}$and NADPH [42]. Schuit et al. [43] have reported that citrate and malate accumulate in beta cells under stimulation by high glucose, and this accumulation is associated with insulin release. On the other hand, mitochondrial citrate may be the precursor of cataplerotic signalling molecules, such as malonyl-CoA, that are implicated in the $\mathrm{K}_{\text {ATP }}^{+}$-channel-independent pathway of insulin secretion $[44,45]$. In addition, the entry of glutamine into the cycle (one of the anaplerotic pathways) is also known to regulate insulin secretion [46, 47], and glutamine metabolism may be involved in the pyruvate-malate shuttle [35]. Because $\mathrm{ME}$ is located in the anaplerotic/cataplerotic pathways, it may play a role in balancing these pathways.

The ME activity level in mouse primary islets is lower than that in rat islets, and our results are consistent with a previous observation [48]; this might be the reason why ME activity could not be measured by a routine method that was used to measure rat islet ME activity [21-23], and why methyl succinate increases insulin secretion in rat islets but not in mouse islets [21]. In addition, it has been reported that blood glucose and insulin levels are normal in Mod-1 mice, which lack cytoplasmic ME in all tissues [22, 49]; this phenomenon argues against a critical role for the pyruvate-malate shuttle in insulin secretion. This might suggest that the roles of ME are limited in mouse primary beta cells in normal physiological conditions. This phenomenon forced us to reconsider the roles of ME in mouse islets. A low level of islet ME might be allowable and not affect energy metabolism or not be important in normal mice. However, ME may play important roles in some pathophysiological conditions. For example, ME might be important for beta cell adaptation to insulin resistance in obese mice. As shown in Fig. 4a, ME activity was increased twofold more than in $\mathrm{AyL}$ obese and insulin-resistant mice. ME perhaps plays important roles in enhancing beta cell adaptation to insulin resistance, inducing them to secrete more insulin and leading to hyperinsulinaemia during obesity. If there is no ME in beta cells, obese mice might more easily develop type 2 diabetes. We have 
shown that the pyruvate-malate shuttle plays an important role in insulin secretion $[2,39]$ and beta cell adaptation $[13$, 15], and mouse islet ME has recently been reported to be involved in the pyruvate-malate shuttle activity [35].

In summary, we have demonstrated that mouse islets possess $\mathrm{ME}$ activity and that this activity helps regulate insulin secretion. Increased ME activity in the islets of obese mice might play important roles in beta cell adaptation to insulin resistance.

Acknowledgements This work was supported by grants to Y. Q. Liu from the National Institutes of Health (P20 RR/DE17702 from the COBRE Program of the National Center for Research Resources, and 1R01 DK077624-01), the American Diabetes Association (Junior Faculty Award). This project was also supported by a grant (6931) from The Research Institute for Children, Children's Hospital at New Orleans. The authors thank S. Ozcan of the University of Kentucky for providing MIN-6 cells and M. Hara of the University of Chicago for the beta cell GFP transgenic mice. We also thank M. MacDonald of the University of Wisconsin Medical School for his advice on the ME activity assay. The preliminary data included here were presented at the 67th ADA Scientific Sessions Annual Meeting, 2007, Chicago, IL, USA.

Duality of interest The authors declare that there is no duality of interest associated with this manuscript.

\section{References}

1. Macdonald MJ (1995) Feasibility of a mitochondrial pyruvate malate shuttle in pancreatic islets. Further implication of cytosolic NADPH in insulin secretion. J Biol Chem 270:20051-20058

2. Lu D, Mulder H, Zhao P et al (2002) 13C NMR isotopomer analysis reveals a connection between pyruvate cycling and glucose-stimulated insulin secretion (GSIS). Proc Natl Acad Sci USA 99:2708-2713

3. Costa Rosa LF, Curi R, Murphy C, Newsholme P (1995) Effect of adrenaline and phorbol myristate acetate or bacterial lipopolysaccharide on stimulation of pathways of macrophage glucose, glutamine and $\mathrm{O}_{2}$ metabolism. Evidence for cyclic AMP-dependent protein kinase mediated inhibition of glucose-6-phosphate dehydrogenase and activation of $\mathrm{NADP}^{+}$-dependent 'malic' enzyme. Biochem J 310:709-714

4. Infante JP, Huszagh VA (1998) Analysis of the putative role of 24carbon polyunsaturated fatty acids in the biosynthesis of docosapentaenoic $(22: 5 n-6)$ and docosahexaenoic $(22: 6 n-3)$ acids. FEBS Lett 431:1-6

5. Dmitriev LF (2001) Activity of key enzymes in microsomal and mitochondrial membranes depends on the redox reactions involving lipid radicals. Membr Cell Biol 14:649-662

6. Lee SM, Koh HJ, Park DC, Song BJ, Huh TL, Park JW (2002) Cytosolic NADP(+)-dependent isocitrate dehydrogenase status modulates oxidative damage to cells. Free Radic Biol Med 32:1185-1196

7. Sheline CT, Choi DW (1998) Neuronal death in cultured murine cortical cells is induced by inhibition of GAPDH and triosephosphate isomerase. Neurobiol Dis 5:47-54

8. Brune B, Dimmeler S, Lapetina EG (1992) NADPH: a stimulatory cofactor for nitric oxide-induced ADP-ribosylation reaction. Biochem Biophys Res Commun 182:1166-1171

9. Menendez J, Delgado J, Gancedo C (1998) Isolation of the Pichia pastoris $\mathrm{PYC} 1$ gene encoding pyruvate carboxylase and identification of a suppressor of the pyc phenotype. Yeast $14: 647-654$

10. Macdonald MJ (2003) Export of metabolites from pancreatic islet mitochondria as a means to study anaplerosis in insulin secretion. Metabolism 52:993-998

11. Ivarsson R, Quintens R, Dejonghe S et al (2005) Redox control of exocytosis: regulatory role of NADPH, thioredoxin, and glutaredoxin. Diabetes 54:2132-2142

12. Macdonald MJ, Kaysen JH, Moran SM, Pomije CE (1991) Pyruvate dehydrogenase and pyruvate carboxylase. Sites of pretranslational regulation by glucose of glucose-induced insulin release in pancreatic islets. J Biol Chem 266:22392-22397

13. Liu YQ, Jetton TL, Leahy JL (2002) beta-Cell adaptation to insulin resistance. Increased pyruvate carboxylase and malatepyruvate shuttle activity in islets of nondiabetic Zucker fatty rats. J Biol Chem 277:39163-39168

14. Liu YQ, Moibi JA, Leahy JL (2004) Chronic high glucose lowers pyruvate dehydrogenase activity in islets through enhanced production of long chain acyl-CoA: prevention of impaired glucose oxidation by enhanced pyruvate recycling through the malate-pyruvate shuttle. J Biol Chem 279:7470-7475

15. Liu YQ, Han J, Epstein PN, Long YS (2005) Enhanced rat betacell proliferation in $60 \%$ pancreatectomized islets by increased glucose metabolic flux through pyruvate carboxylase pathway. Am J Physiol Endocrinol Metab 288:E471-E478

16. Ronnebaum SM, Ilkayeva O, Burgess SC et al (2006) A pyruvate cycling pathway involving cytosolic NADP-dependent isocitrate dehydrogenase regulates glucose-stimulated insulin secretion. J Biol Chem 281:30593-30602

17. Jensen MV, Joseph JW, Ilkayeva O et al (2006) Compensatory responses to pyruvate carboxylase suppression in islet beta-cells. Preservation of glucose-stimulated insulin secretion. J Biol Chem 281:22342-22351

18. Macdonald MJ, Fahien LA, Brown LJ, Hasan NM, Buss JD, Kendrick MA (2005) Perspective: emerging evidence for signaling roles of mitochondrial anaplerotic products in insulin secretion. Am J Physiol Endocrinol Metab 288:E1-E15

19. Guay C, Madiraju SR, Aumais A, Joly E, Prentki M (2007) A role for ATP-citrate lyase, malic enzyme, and pyruvate/citrate cycling in glucose-induced insulin secretion. J Biol Chem 282:3565735665

20. Khan A, Ling ZC, Landau BR (1996) Quantifying the carboxylation of pyruvate in pancreatic islets. J Biol Chem 271:2539-2542

21. Macdonald MJ (2002) Differences between mouse and rat pancreatic islets: succinate responsiveness, malic enzyme, and anaplerosis. Am J Physiol Endocrinol Metab 283:E302-E310

22. Macdonald MJ, Marshall LK (2001) Survey of normal appearing mouse strain which lacks malic enzyme and $\mathrm{Nad}^{+}$-linked glycerol phosphate dehydrogenase: normal pancreatic beta cell function, but abnormal metabolite pattern in skeletal muscle. Mol Cell Biochem 220:117-125

23. Heart E, Yaney GC, Corkey RF et al (2007) $\mathrm{Ca}^{2+}, \mathrm{NAD}(\mathrm{P}) \mathrm{H}$ and membrane potential changes in pancreatic beta-cells by methyl succinate: comparison with glucose. Biochem J 403:197-205

24. Hara M, Wang X, Kawamura T et al (2003) Transgenic mice with green fluorescent protein-labeled pancreatic beta-cells. Am J Physiol Endocrinol Metab 284:E177-E183

25. Gotoh M, Maki T, Satomi S et al (1987) Reproducible high yield of rat islets by stationary in vitro digestion following pancreatic ductal or portal venous collagenase injection. Transplantation 43:725-730

26. Labarca C, Paigen K (1980) A simple, rapid, and sensitive DNA assay procedure. Anal Biochem 102:344-352

27. Mosley AL, Ozcan S (2004) The pancreatic duodenal homeobox-1 protein $(\mathrm{Pdx}-1)$ interacts with histone deacetylases Hdac-1 and Hdac-2 on low levels of glucose. J Biol Chem 279:54241-54247 
28. Schuppin GT, Bonner-Weir S, Montana E, Kaiser N, Weir GC (1993) Replication of adult pancreatic-beta cells cultured on bovine corneal endothelial cell extracellular matrix. In Vitro Cell Dev Biol Anim 29A:339-344

29. Xu J, Han J, Epstein PN, Liu YQ (2006) Regulation of PDK mRNA by high fatty acid and glucose in pancreatic islets. Biochem Biophys Res Commun 344:827-833

30. Pfaffl MW (2001) A new mathematical model for relative quantification in real-time RT-PCR. Nucleic Acids Res 29: e45

31. Xu J, Han J, Long YS, Epstein PN, Liu YQ (2008) The role of pyruvate carboxylase in insulin secretion and proliferation in rat pancreatic beta cells. Diabetologia doi:10.1007/s00125-008$1130-9$

32. Lowry OH, Passonneau JV (1972) Enzymatic cycling. In: Lowry $\mathrm{OH}$, Passonneau JV (eds) A flexible system of enzymatic analysis. Academic Press, New York, pp 129-145

33. Patel YC, Weir GC (1976) Increased somatostatin content of islets from streptozotocin-diabetic rats. Clin Endocrinol (Oxf) 5:191194

34. Soeller WC, Janson J, Hart SE et al (1998) Islet amyloidassociated diabetes in obese $\mathrm{A}(\mathrm{vy}) / \mathrm{a}$ mice expressing human islet amyloid polypeptide. Diabetes 47:743-750

35. Li C, Nissim I, Chen P et al (2008) Elimination of KATP channels in mouse islets results in elevated $\left[\mathrm{U}^{13} \mathrm{C}\right]$ glucose metabolism, glutaminolysis, and pyruvate cycling but a decreased $\gamma$-aminobutyric acid shunt. J Biol Chem 283:17238-17249

36. Iizuka K, Nakajima H, Namba M et al (2002) Metabolic consequence of long-term exposure of pancreatic beta cells to free fatty acid with special reference to glucose insensitivity. Biochim Biophys Acta 1586:23-31

37. Eto K, Suga S, Wakui M et al (1999) NADH shuttle system regulates $\mathrm{K}_{\mathrm{ATP}}$ channel-dependent pathway and steps distal to cytosolic $\mathrm{Ca}^{2+}$ concentration elevation in glucose-induced insulin secretion. J Biol Chem 274:25386-25392

38. Min L, Leung YM, Tomas A et al (2007) Dynamin is functionally coupled to insulin granule exocytosis. J Biol Chem 282:3353033536
39. Cline GW, LePine RL, Papas KK, Kibbey RG, Shulman GI (2004) ${ }^{13} \mathrm{C}$-NMR isotopomer analysis of anaplerotic pathways in INS-1 cells. J Biol Chem 279:44370-44375

40. Pongratz RL, Kibbey RG, Shulman GI, Cline GW (2007) Cytosolic and mitochondrial malic enzyme isoforms differentially control insulin secretion. J Biol Chem 282:200-207

41. Flamez D, Berger V, Kruhoffer M, Orntoft T, Pipeleers D, Schuit FC (2002) Critical role for cataplerosis via citrate in glucoseregulated insulin release. Diabetes 51:2018-2024

42. Farfari S, Schulz V, Corkey B, Prentki M (2000) Glucoseregulated anaplerosis and cataplerosis in pancreatic beta cells: possible implication of a pyruvate/citrate shuttle in insulin secretion. Diabetes 49:718-726

43. Schuit F, De Vos A, Farfari S et al (1997) Metabolic fate of glucose in purified islet cells. Glucose-regulated anaplerosis in beta cells. J Biol Chem 272:18572-18579

44. Maechler P, Kennedy ED, Pozzan T, Wollheim CB (1997) Mitochondrial activation directly triggers the exocytosis of insulin in permeabilized pancreatic beta-cells. EMBO J 16:3833-3841

45. Wollheim CB, Maechler P (2002) Beta-cell mitochondria and insulin secretion: messenger role of nucleotides and metabolites. Diabetes 51(Suppl 1):S37-S42

46. Newsholme P, Bender K, Kiely A, Brennan L (2007) Amino acid metabolism, insulin secretion and diabetes. Biochem Soc Trans 35:1180-1186

47. Corless M, Kiely A, McClenaghan NH, Flatt PR, Newsholme P (2006) Glutamine regulates expression of key transcription factor, signal transduction, metabolic gene, and protein expression in a clonal pancreatic beta-cell line. J Endocrinol 190:719-727

48. Ashcroft SJ, Randle PJ (1970) Enzymes of glucose metabolism in normal mouse pancreatic islets. Biochem J 119:5-15

49. Lee CY, Lee SM, Lewis S, Johnson FM (1980) Identification and biochemical analysis of mouse mutants deficient in cytoplasmic malic enzyme. Biochemistry 19:5098-5103

50. Applied Biosystems. User Bulletin \#2, 11 December 1997 (updated 10/2001). Available from http://www3.appliedbiosystems.com/cms/ groups/mcb_support/documents/generaldocuments/cms_040980. pdf, accessed 22 August 2008 